\title{
Sulfhydryl Oxidase in Human Milk: Stability of Milk Enzymes in the Gastrointestinal Tract
}

\author{
CHARLES E. ISAACS, ${ }^{(42)}$ THERESA PASCAL, CHARLES E. WRIGHT, AND GERALD E. GAULL \\ Department of Human Development and Nutrition, New York State Institute for Basic Research in \\ Developmental Disabilities, Staten Island, New York, USA
}

\begin{abstract}
Summary
Sulfhydryl oxidase (SOX) is present in human milk and in milk from all species that have been studied. The $\mathrm{pH}$ optimum of human milk SOX is in the neutral range between 7.0 and 7.5. Human milk SOX is stable in an acid environment: $50 \%$ of its activity remains after $1 \mathrm{~h}$ at $\mathrm{pH} 2.5$. Acid stability is also characteristic of $\gamma$-glutamyltranspeptidase, another membranebound enzyme in skim milk. SOX is resistant to pepsin $(4000 \mathrm{U} /$ $\mathrm{ml})$, trypsin $(50 \mu \mathrm{g} / \mathrm{ml})$, chymotrypsin $(200 \mu \mathrm{g} / \mathrm{ml})$, and to trypsin plus chymotrypsin $(25 \mu \mathrm{g}$ each/ml). Milk SOX activity has been detected in the stomach and proximal small intestine contents of suckling rats. Human and bovine SOX are relatively heat stable: $75 \%$ of the latter remains after treatment at $62.5^{\circ} \mathrm{C}$ for $30 \mathrm{~min}$ and $65 \%$ of the former remains after treatment at $60^{\circ} \mathrm{C}$ for 10 min. Neither remains after $62.5^{\circ} \mathrm{C}$ for $30 \mathrm{~min}$.
\end{abstract}

\section{Abbreviations}

DTT, dithiothreitol

GGT, $\gamma$-glutamyltranspeptidase

GI, gastrointestinal

GSH, reduced glutathione

GSSG, oxidized glutathione

SIgA, secretory IgA

SOX, sulfhydryl oxidase

Some 60-70 enzymes have been reported to be present in milk $(4,35)$ but little is known about their function. Milk enzymes may act in the milk itself, in the intestine, or may be absorbed by intestinal epithelial cells and transported to target tissues. At least two human milk enzymes, bile salt-stimulated lipase and mammary amylase, have been shown to play a physiologic role in the digestion of milk nutrients $(15,18,19,22,23,28)$. It is unlikely, considering the strict control of secretory processes (29), that a significant number of enzymes occur in milk simply because of "spillage" from the blood or acinar cells.

Sulfhydryl oxidases are a class of enzymes that catalyze the net synthesis of disulfide bonds (21). These enzymes use molecular oxygen and both low molecular weight sulfhydryl compounds and protein sulfhydryls as substrates in vitro $(3,31,34)$; they produce $\mathrm{H}_{2} \mathrm{O}_{2}$ plus a disulfide. Sulfhydryl oxidases were originally described in bovine milk (24) but have subsequently been found in skin (38), seminal vesicle (31), epididymis (6), and in mouse plasmacytomas producing IgM (34). The in vivo substrates for SOX in mouse plasmacytomas were shown to be IgM monomers and the associated $\mathbf{J}$ chain (34). But in vivo substrates for the sulfhydryl oxidases found in mammalian secretions and tissues have not been established. Milk SOX might play a role in altering the structure of milk or intestinal proteins that are dependent upon the redox state of their sulfhydryls for function.
The present experiments were designed to determine whether or not SOX and other milk enzymes had stability characteristics similar to those of milk proteins, such as secretory immunoglobulins $(13,25)$, which have been shown to be active in the gastrointestinal tract of the suckling neonate. Studies, both in vitro and in vivo, were done in order to measure the stability of SOX to acid and to gut protease.

\section{MATERIALS AND METHODS}

Human milk samples were obtained through the La Leche League of Staten Island. The milk was frozen immediately after collection from the donor. Informed consent was obtained from the donors by the La Leche League. Unprocessed bovine milk was obtained from a local dairy farm. Pregnant Sprague-Dawley rats and New Zealand white rabbits were obtained from Charles River Farms (Wilmington, MA). Pepsin, chymotrypsin, trypsin, dithiothreitol, glutathione, $\gamma$-glutamyl- $p$-nitroanilide, glycylglycine, $p$-dinitrophenylphosphate, NADH, and pyruvate were purchased from Sigma (St. Louis, MO).

Milk samples. Milk from rats and rabbits was obtained by anesthetizing lactating females by injection with $10 \mathrm{mg}$ of sodium pentobarbital, stimulating milk secretion when necessary with oxytocin ( $0.5 \mathrm{IU}$ in $0.5 \mathrm{ml}$ of $0.9 \%$ saline) and then manually expressing the milk.

Enzyme assays. SOX activity was determined by measuring the disappearance of free substrate sulfhydryls at $37^{\circ} \mathrm{C}$, using 5,5'-dithiobis (2-nitrobenzoic acid) (12). The enzyme assay was performed at pH 7.0 in $50 \mathrm{mM}$ sodium phosphate buffer with DTT or GSH at a sulfhydryl concentration of $0.8 \mathrm{mM}$. A total reaction volume of $1.2 \mathrm{ml}$ was used and $300 \mu \mathrm{L}$ was taken for sulfhydryl determination. GGT (E.C. 2.3.2.2) was measured by the method of Griffith and Tate (16), using p-nitroanilide as substrate at $25^{\circ} \mathrm{C}$. Alkaline phosphatase (E.C. 3.1.3.1) was determined at $25^{\circ} \mathrm{C}$ by the method of Lowry (27), which measures $p$ nitrophenol production. Lactate dehydrogenase (E.C. 1.1.1.27) activity was determined at $25^{\circ} \mathrm{C}$ by the disappearance of NADH absorption at $340 \mathrm{~nm}$, using pyruvate as substrate (9). Proteins were measured by the method of Bradford (5).

Protease treatment of milk. For pepsin treatment, whole human milk was adjusted to $\mathrm{pH} 3.5$ before pepsin was added. After a 2 -h incubation at $37^{\circ} \mathrm{C}$, pepsin digestion was stopped by raising the $\mathrm{pH}$ to 7.0 with $0.1 \mathrm{~N} \mathrm{NaOH}$. The milk was then spun at $16,000 \mathrm{~g}$ for $30 \mathrm{~min}$ at $4^{\circ} \mathrm{C}$ and the supernatant assayed for SOX. Trypsin and chymotrypsin were added to whole human milk and the milk was incubated at $37^{\circ} \mathrm{C}$ for $2 \mathrm{~h}$. The milk was then cooled to $4^{\circ} \mathrm{C}$ spun at $16,000 \mathrm{~g}$ for $30 \mathrm{~min}$ and the supernatant was assayed for SOX. Protease concentrations used were in excess of those found in the GI tract of the newborn infant (1).

Heat treatment of milk. Milk samples were placed in a heat block set at the appropriate temperature and allowed to equilibrate; they were then kept at temperature for the indicated time. 
Table 1. Sulfhydryl oxidase (SOX) in milk*

\begin{tabular}{|c|c|c|c|c|}
\hline \multirow[b]{3}{*}{ Milk source } & \multicolumn{4}{|c|}{ SOX activity } \\
\hline & \multicolumn{2}{|c|}{ DTT utilization $†$} & \multicolumn{2}{|c|}{ GSH utilization $\dagger$} \\
\hline & {$[\mathrm{nmol} /(\min \cdot \mathrm{mg}$ protein $)]$} & {$[\mathrm{nmol} /(\mathrm{min} \cdot \mathrm{ml} \mathrm{milk})]$} & $\begin{array}{c}{[\mathrm{nmol} /(\mathrm{min} \cdot \mathrm{mg} \text { pro- }} \\
\text { tein })]\end{array}$ & {$[\mathrm{nmol} /(\mathrm{min} \cdot \mathrm{ml}$ milk $)]$} \\
\hline Human & $39.3 \pm 2.9(7)$ & $901 \pm 66.0(7)$ & 0 & 0 \\
\hline Rat & $94.5 \pm 12.0(3)$ & $3273 \pm 517(3)$ & 0 & 0 \\
\hline Rabbit & 5.2 & 316 & 7.6 & 464 \\
\hline Bovine (dairy cow) & $6.1 \pm 1.2(3)$ & $204.6 \pm 27.1(3)$ & $8.0 \pm 1.8(7)$ & $234.9 \pm 34.3(7)$ \\
\hline Bovine (colostrum) & 4.5 & 148.6 & 7.5 & 250.4 \\
\hline
\end{tabular}

* Values where indicated are mean $\pm \mathrm{SD}$. The numbers of samples assayed are indicated in brackets.

$\dagger$ Abbreviations: DTT, dithiothreitol and GSH, reduced glutathione.

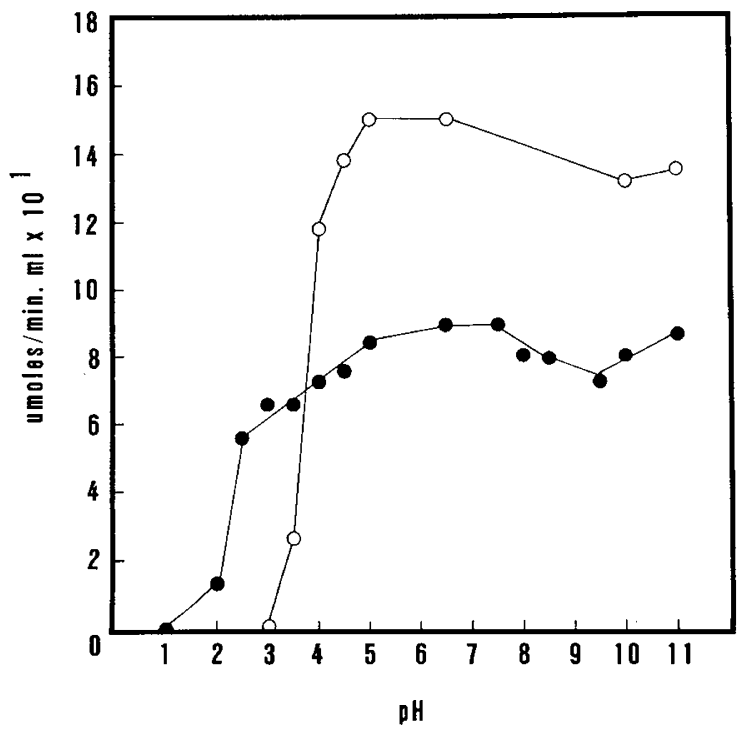

Fig. 1. pH stability of sulfhydryl oxidase (SOX) $(\bullet)$ and $\gamma$-glutamyltranspeptidase $(G G T)(O)$ in human milk.

$\mathrm{pH}$ stability studies. Milk was adjusted to the indicated $\mathrm{pH}$ with either $0.01 \mathrm{~N} \mathrm{HCl}$ or $0.1 \mathrm{~N} \mathrm{NaOH}$ and kept there for $1 \mathrm{~h}$. It was then brought back to $\mathrm{pH} 7.0$ and assayed for enzyme activity.

\section{RESULTS}

SOX is present in milk from all species that have been studied (7) (Table 1), including milk from lactating females without nursing offspring, i.e., milk from dairy cows. Rat milk has the highest concentration of SOX, measured either as total SOX activity per $\mathrm{ml}$ or on the basis of protein concentration. SOX in human and rat milk utilizes reduced DTT as substrate but not GSH. Bovine and rabbit milk SOX, however, utilize both DTT and GSH as substrates and produce oxidized DTT and GSSG at almost equal rates. DTT-specific SOX has much greater activity, per ml milk or per mg protein, than SOX of the cow and rabbit milk. SOX both from human and from bovine milk is able to oxidize cysteine (data not shown). SOX activity is equivalent in bovine colostrum and dairy cow milk and has the same substrate specificity.

Human milk SOX activity is very stable in an acid environment (Fig. 1). No activity is lost at $\mathrm{pH} 4.0,75-80 \%$ of the activity remains at $\mathrm{pH} 3.0$, and greater than $50 \%$ resists exposure to $\mathrm{pH}$ 2.5. Human milk SOX is not inactivated at alkaline $\mathrm{pH}$; greater than $90 \%$ of SOX activity remains at $\mathrm{pH} 11$. Acid stability is also characteristic of GGT, another skim milk, membrane-bound enzyme (Fig. 1). GGT is not as acid stable as SOX but still retains greater than $70 \%$ of its activity at $\mathrm{pH} 4.0$. The difference in acid stability between the two enzymes indicates that milk
Table 2. Resistance of human milk sulfhydryl oxidase (SOX) to gastrointestinal protease

\begin{tabular}{ll}
\hline \multicolumn{1}{c}{$\quad$ Protease } & $\begin{array}{c}\text { SOX activity remaining } \\
{[\mathrm{nmol} /(\mathrm{min} \cdot \mathrm{ml})]}\end{array}$ \\
\hline None & 477.6 \\
Pepsin & \\
$\quad(2000 \mathrm{U} / \mathrm{ml})$ & 486.8 \\
$(4000 \mathrm{U} / \mathrm{ml})$ & 205.9 \\
Trypsin & \\
$(50 \mu \mathrm{g} / \mathrm{ml})$ & 398.7 \\
$(200 \mu \mathrm{g} / \mathrm{ml})$ & 59.0 \\
Chymotrypsin & \\
$(50 \mu \mathrm{g} / \mathrm{ml})$ & 492.0 \\
$(200 \mu \mathrm{g} / \mathrm{ml})$ & 191.2 \\
Trypsin $+\mathrm{chymotrypsin}$ & 455.6 \\
$(25 \mu \mathrm{g} \mathrm{each} / \mathrm{ml})$ & 93.8 \\
$(50 \mu \mathrm{g}$ each/ml $)$ & 0 \\
$(100 \mu \mathrm{g} \mathrm{each} / \mathrm{ml})$ & \\
\hline
\end{tabular}

SOX activity does not require previous GGT activity, as has been suggested for renal SOX (16). At pH 3.5 and below, there is greater SOX than GGT activity on a molar basis.

Studies were done in order to determine the susceptibility of SOX to GI proteases (Table 2). With $4000 \mathrm{U} / \mathrm{ml}$ of pepsin in human milk, $40-45 \%$ of SOX activity remains after $90 \mathrm{~min}$. The enzyme is also relatively resistant to chymotrypsin. Trypsin at $50 \mu \mathrm{g} / \mathrm{ml}$ causes only minor loss of activity and even with 200 $\mu \mathrm{g} / \mathrm{ml}$ of trypsin $10-15 \%$ of SOX activity remains. When trypsin and chymotrypsin were used together $(25 \mu \mathrm{g} / \mathrm{ml}$ each $)$, SOX was not inactivated; however, when $100 \mu \mathrm{g} / \mathrm{ml}$ of each was used for digestion all SOX activity was eliminated.

SOX from human and bovine milk is relatively heat stable (Table 3). Pasteurization of bovine milk $\left(62.5^{\circ} \mathrm{C}, 30 \mathrm{~min}\right)$ inactivates only $25 \%$ of SOX activity. Human milk SOX is somewhat less heat stable than the bovine enzyme, but $65 \%$ of the activity remains at $65^{\circ} \mathrm{C}$ after $10 \mathrm{~min}$. This degree of heat stability is also characteristic of some other human milk proteins that function in the GI tract, e.g., lactoferrin and SIgA.

The pH optimum of human milk SOX is between 7.0 and 7.5 (Fig. 2). We were unable to find a second $\mathrm{pH}$ optimum below 6.0 (data not shown), which indicates that SOX would have almost maximal activity in the small intestine and partial activity within the bolus in the stomach.

Enzyme assays were performed on the stomach contents of 7 to 9-d-old suckling rats (Table 4). Activity was detected for the membrane-bound enzymes SOX, GGT, and alkaline phosphatase and for lactate dehydrogenase, the soluble milk enzyme. Measurements of the contents of the proximal small intestine indicated that rat milk SOX and GGT passed from the stomach into the intestine. Because SOX activity was measured with DTT, it is derived from milk and is not intestinal SOX activity, which utilizes GSH (16). 
Table 3. Heat treatment of human and bovine sulfhydryl oxidase (SOX)

\begin{tabular}{lcc}
\hline \multicolumn{1}{c}{ Treatment } & $\begin{array}{c}\text { \% SOX remaining } \\
\text { human milk }\end{array}$ & $\begin{array}{c}\text { \% SOX remaining } \\
\text { bovine milk }\end{array}$ \\
\hline None & 100 & 100 \\
$50^{\circ} \mathrm{C}, 10 \mathrm{~min}$ & 100 & $\ldots$ \\
$50^{\circ} \mathrm{C}, 20 \mathrm{~min}$ & 59.5 & $\ldots$ \\
$60^{\circ} \mathrm{C}, 10 \mathrm{~min}$ & 65 & $\ldots$ \\
$62.5^{\circ} \mathrm{C}, 30 \mathrm{~min}$ & 0 & 75 \\
$65^{\circ} \mathrm{C}, 30 \mathrm{~min}$ & 0 & 64 \\
$70^{\circ} \mathrm{C}, 30 \mathrm{~min}$ & 0 & 18 \\
$100^{\circ} \mathrm{C}, 10 \mathrm{~min}$ & 0 & 0 \\
\hline
\end{tabular}

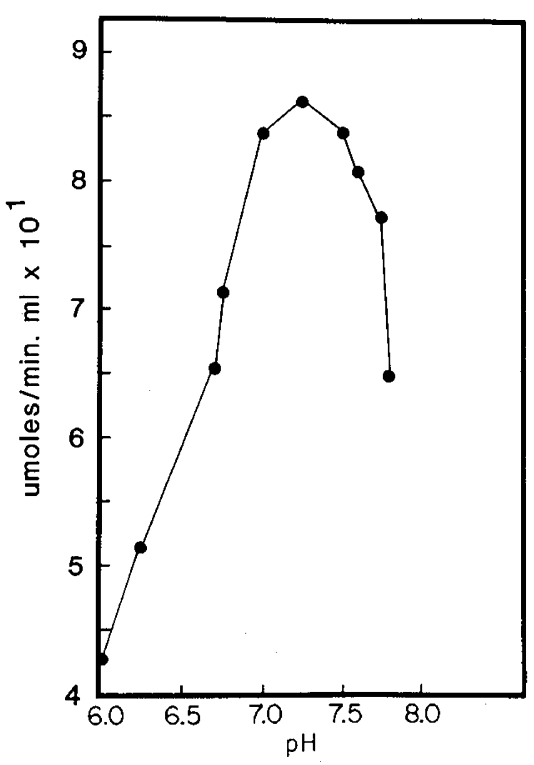

Fig. 2. pH optimum of human milk sulfhydryl oxidase (SOX). Assays were performed on milk that was centrifuged at $16,000 \mathrm{~g}$ for $30 \mathrm{~min}$.

\section{DISCUSSION}

SOX has been found in the milk of all species tested (7) (Table 1), suggesting that this enzyme performs an important function in milk or in the suckling neonate of all mammals. The differences found in substrate specificity in vitro do not necessarily imply any substrate differences in vivo. All milk SOXs may perform the same in vivo function.

The acid stability of SOX and other milk enzymes and the resistance of SOX to heat denaturation are characteristics shared with other milk proteins that have been shown to be functional in the small intestine, e.g., lactoferrin and $\operatorname{SIgA}(4,25,30)$. The $\mathrm{pH}$ optimum of SOX between 7.0 and 7.5 indicates that its activity in the gastric contents will be minimal because there is a $\mathrm{pH}$ range in the contents of 4.5-5.5 (17). It has been shown, though (Margit Hamosh, personal communication), that there is a $\mathrm{pH}$ gradient within the bolus in the stomach from 5.8-6.0 in the fundic area to 2.5 in the pyloric regions, suggesting that milk SOX may function in the bolus. But SOX could function optimally in the intestine, which has a neutral $\mathrm{pH}(10)$. The resistance of SOX to pepsin, trypsin, and chymotrypsin in our in vitro studies suggests that a significant quantity of the enzyme could remain intact in the intestine. Furthermore, all milks studied contain protease inhibitors, e.g., anti-trypsin and anti-chymotrypsin (26), which may decrease the rate of proteolytic digestion in the intestine of the suckling neonate.

The presence of SOX, GGT, alkaline phosphatase, and lactate dehydrogenase in the stomach contents of suckling rats provides in vivo evidence that milk enzymes, in addition to lactoferrin and SIgA, are highly resistant to pepsin degradation. SOX and GGT activities in the contents of the proximal small intestine of
Table 4. Milk enzymes in the gastroinestinal tract of 7- to 9-dold rats*

\begin{tabular}{lcc}
\hline Enzyme & $\begin{array}{c}\text { Specific activity in } \\
\text { stomach contents } \\
\text { [nmol/(min } \cdot \text { mg pro- } \\
\text { tein)] }\end{array}$ & $\begin{array}{c}\text { Specific activity in } \\
\text { proximal small intes- } \\
\text { tine contents [nmol/ } \\
\text { (min } \cdot \text { mg protein)] }\end{array}$ \\
\hline SOX $\dagger$ & $127.0 \pm 24.8(5)$ & 154,429 \\
GGT $\dagger$ & $207.0 \pm 98.6(3)$ & 83,77 \\
Alkaline phosphatase & $8.8 \pm 2.5(3)$ & $\ldots$ \\
Lactase dehydrogenase & $191.2,61.5$ & $\ldots$ \\
\hline
\end{tabular}

$*$ Values where indicated are mean \pm SD. Values in brackets are number of samples from different litters assayed.

$\dagger$ SOX, sulfhydryl oxidase and GGT, $\gamma$-glutamyltranspeptidase.

suckling rats indicate that these two enzymes also are resistant to intestinal proteases and may function at some point in the intestinal tract. It is possible that GGT present in intestinal contents is derived from intestinal tissue; however, the SOX activity that we measured was DTT-specific, whereas "glutathione oxidase" (SOX?) found in small amounts in jejunal villus tip cells is specific for glutathione (39).

Milk SOX may have more than one function, as has been found with D-galactosyltransferase, another milk enzyme (36). The membrane-bound SOX induced in pentameric IgM-secreting mouse plasmacytomas, concomitantly with secretory heavy chain and $\mathbf{J}$ chain, catalyses the formation of disulfide bonds between IgM monomers and $\mathrm{J}$ chain. The primary immunoglobulin in human milk is SIgA, a dimer formed by disulfide linkage of IgA monomers to a $J$ chain. Milk SOX may catalyse IgA dimer formation in the breast and then be secreted into milk with SIgA where it performs an additional function. Possible other roles for milk SOX are control of milk enzymes which are dependent upon the redox state of their sulfhydryls for function, e.g., glucose-6-phosphate dehydrogenase (11), attachment of SIgA to intestinal mucins (40), and alteration of the mucous diffusion barrier that has been proposed by Smithson et al. (37). The protein component of mucins is a tetramer held together by disulfide linkages $(2,14,32)$. Milk SOX has been shown in vitro to have the capability to oxidize not only low molecular weight thiols $(3,21)$ but also to reform correctly the disulfide bonds in chymotrysinogen A (20) and ribonuclease (21) and to convert milk xanthine oxidase from the dehydrogenase to the oxidase form by oxidation of two vicinal thiols (8). In the intestine, milk SOX may serve an interim role by supplementing immature intestinal or salivary enzyme. We have found SOX to be present in adult saliva $[84 \mathrm{nmol} /(\mathrm{min} \cdot \mathrm{ml})]$ but have not been able to detect SOX activity in saliva from $1-$ and 2-d old infants. SOX in milk may also have a function that is required solely in the immature small intestine.

High molecular weight proteins, such as IgG in suckling rats (33), can be absorbed by the proximal small intestine. The ability of suckling rats to absorb IgG decreases as the rat approaches weaning $(21 \mathrm{~d})$. It is thus possible that some milk enzymes may also be absorbed by the intestine and then transported by the circulatory system to their site of action. SOX may play a role in the intestinal absorption of proteins by altering the mucoprotein surface coat of the small intestine in suckling neonates. Experiments are presently underway to determine the site of action of milk SOX and to elucidate its in vivo substrate(s).

\section{REFERENCES AND NOTES}

1. Agunod, M., Yamaguchi, N., Lopez, R., Luhby, A. L., and Glass, G. B. J.: Correlative study of hydrochloric acid, pepsin, and intrinsic factor secretion in newborns and infants. Am. J. Dig. Dis., 14: 400 (1969).

2. Allen, A.: Structure of gastrointestinal mucous glycoproteins and the viscous and gel-forming properties of mucous. Br. Med. Bull., 34: 28 (1978).

3. Ashkar, S., Binkley, F., and Jones. D. P.: Resolution of a renal sulfhydryl (glutathionine) oxidase from $\gamma$-glutamyltransferase. FEBS Lett., I24: 166 (1981). 
4. Blanc, B.: Biochemical aspects of human milk-comparison with bovine milk. World Rev. Nutr. Diet, 36: 1 (1981).

5. Bradford, M. M.: A rapid and sensitive method for the quantitation of microgram quantities of protein utilizing the principle of protein-dye binding. Anal. Biochem., 72: 248 (1976).

6. Chang. T. S. K. and Morton, B.: Epididymal sulfhydryl oxidase. A spermprotective enzyme from the male reproductive tract. Biochem. Biophys. Res. Commun., 66: 309 (1975).

7. Clare, D. A., Sliwkowski, M. B., Horton, H. R., and Swaisgood, H. E.: Activity solubilization and distribution of sulfhydryl oxidase. Fed. Proc., 39: 1696 (1980).

8. Clare, D. A., Blakistone, B. A., Swaisgood, H. E., and Horton, H.R .: Sulfhydryl oxidase-catalyzed conversion of xanthine dehydrogenase to xanthine oxidase. Arch. Biochem. Biophys., 211: 44 (1981)

9. Decker, L. A. (ed.): In: Worthington Enzyme Manual. p. 19 (Freehold, New Jersey, 1977).

10. Diem, K. (ed.). Scientific Tables (Sixth Edition) (Ciba-Geigy Pharmaceuticals, Ardsley 1962)

11. Eggleston, L. V. and Krebs, H. A.: Regulation of the pentose phosphate cycle. Biochem. J., 138: 425 (1974).

12. Ellman, G. L.: Tissue sulfhydryl groups. Arch. Biochem. Biophys., 82: 70 (1959).

13. Evans, T. J., Riley, H. C., Neale, L. M., Dodge, J. A., and Lewarne, V. M. Effect of storage and heat on antimicrobial proteins in human milk. Arch. Dis. Child., 53: 239 (1978).

14. Fahim, R. E. F., Forstner, G. G., and Forstner, J. F.: Heterogeneity of rat goblet-cell mucin before and after reduction. Biochem. J., 209: 117 (1983)

15. Fredrikson, B., Hernell, O., Blackberg L., and Olivecrona, T.: Bile salt-stimulated lipase in human milk: evidence of activity in vivo and of a role in the digestion of milk retinol esters. Pediatr. Res., 12: 1048 (1978).

16. Griffith, O. W. and Tate, S. S.: The apparent glutathione oxidase activity of $\gamma$ glutamyltranspeptidase. J. Biol. Chem., 255: 5011 (1980).

17. Hamosh, M. and Scow, R. O.: Lingual lipase and its role in the digestion of dietary lipid. J. Clin. Invest., 52: 88 (1973)

18. Heitlinger, L. A., Lee, P. C., Dillon, W. P., and Lenbenthal, E.: Mammary amylase: a possible alternate pathway of carbohydrate digestion in infancy. Pediatr. Res., 17: 15 (1983).

19. Hernell, O. and Olivecrona, T.: Human milk lipases. II. Bile salt stimulated lipase. Biochim. Biophys. Acta, 369: 234 (1974).

20. Janolino, V. G., Sliwkowski, M. X., Swaisgood, H. E. and Horton, H. R.: Catalytic effect of sulfhydryl oxidase on the formation of three-dimensional structure in chymotrypsinogen A. Arch. Biochem. Biophys., 191:269 (1978).

21. Janolino, V. G. and Swaisgood, H. E.: Isolation and characterization of sulfhydryl oxidase from bovine milk. J. Biol. Chem., 250: 2532 (1975).

22. Jensen, R. G., Clark, R. M., de Jong, F. A., Hamosh, M., Liao, T. H., and Mehta, N. R.: The lipolytic triad: human lingual, breast milk, and pancreatic lipases: physiological implications of their characteristics in digestion of dietary fats. J. Pediatr. Gastrol. Nutr., 1: 243 (1982).

23. Jones, J. B., Mehta, N. R. and Hamosh, M.: $\alpha$-Amylase in preterm human milk. J. Pediatr. Gastroenterol. Nutr. 1: 317 (1982)

24. Kiermeier, F. and Petz, E.: Über ein sulfhydrylgruppenoxydierendes Enzym in der milch. Z. Lebensm. Unters.-forsch. 132: 342 (1967).

25. Kraehenbuhl, J. P., Bron, C., and Sordat, B.: Transfer of humoral, secretory and cellular immunity from mother to offspring. In: E. Grundmann and W. H. Kirsten: Current Topics in Pathology. Vol. 66. p. 105 (Springer-Verlag, Berlin, 1979).

26. Lindberg, T.: Protease inhibitors in human milk. Pediatr. Res., 13: 969 (1979)

27. Lowry, O. H.: In: S. P. Colowick and N. O. Kaplan: Methods in Enzymology. Vol. 4. p. 371 (Academic Press, New York, 1957).

28. Mehta, N. R., Jones, J. B., and Hamosh, M.: Lipases in preterm human milk: ontogeny and physiological significance. J. Pediatr., Gastroenterol. Nutr., 1 317 (1982).

29. Mellman, I.: Multiple pathways of membrane transport. Nature, 299: 301 (1982).

30. Nagura, H., Nakane, P. K., and Brown, W. R.: Breastmilk IgA binds to jejunal epithelium in suckling rats. J. Immunol., 120:1333 (1978).

31. Ostrowski, M. C. and Kistler, W. S.: Properties of a flavoprotein sulfhydryl oxidase from seminal vesicle secretion. Biochemistry, 19: 2639 (1980).

32. Roberts, G. P.: The role of disulfide bonds in maintaining the gel structure of bronchial mucus. Arch. Biochem. Biophys., 173: 528 (1976).

33. Rodewald, R.: Intestinal transport of antibodies in the newborn rat. J. Cell Biol., 58: 189 (1973).

34. Roth, R. A. and Koshland, M. E.: Identification of a lymphocyte enzyme that catalyzes pentamer immunoglobulin M assembly. J. Biol. Chem., 256: 4633 (1981).

35. Shahani, K. M., Kean, A. J., and Friend, B. A.: Role and significance of enzymes in human milk. Am. J. Clin. Nutr., 33: 1861 (1980).

36. Smith, C. A. and Brew, K.: Isolation and characteristics of galactosyltransferase from golgi membranes of lactating sheep mammary glands. J. Biol. Chem. 252: 7294 (1977)

37. Smithson, K. W., Millar, D. B., Jacobs, L. R., and Gray, G. M.: Intestinal diffusion barrier: unstirred water layer or membrane surface mucous coat? Science, 214: 1241 (1981)

38. Takamori, K. and Thorp, J. M.: Skin sulfhydryl oxidase purification and some properties. Biochim. Biophys. Acta, 615: 309 (1980).

39. Tate, S. S., Gray, E. M., and Meister, A.: Conversion of glutathione to glutathione disulfide by cell membrane-bound oxidase activity. Proc. Natl. Acad. Sci., 76: 2715 (1979).

40. Walker, W. A. and Isselbacher, K. J.: Intestinal antibodies. N. Engl. J. Med., 297: 767 (1977)

41. We wish to acknowledge the assistance of Mrs. Lynn Stone and other member of the La Leche League of Staten Island for providing us with human milk samples.

42. Requests for reprints should be addressed to: Dr. Charles E. Isaacs, Department of Human Development \& Nutrition, New York State Institute for Basic Research in Developmental Disabilities, Staten Island, NY 10314.

43. Received for publication March 1, 1983.

44. Accepted for publication September 15, 1983. 